\title{
ПОПУЛЯРИЗАЦІЯ ПЕДАГОГІЧНОЇ ТА МЕТОДИЧНОЇ СКЛАДОВИХ У КОРОТКОСТРОКОВИХ ПРОГРАМАХ ПІДВИЩЕННЯ КВАЛІФІКАЦЇ̈ ДЛЯ ВИКЛАДАЧІВ ГАЛУЗЕВИХ ЗАКЛАДІВ ОСВІТИ: ІЗ ДОСВІДУ РОБОТИ НАУКОВО-ПРАКТИЧНОЇ ШКОЛИ-СЕМІНАРУ ТА КВАЛІФІКАЦІЙНОГО ТРЕНІНГУ «СУЧАСНІ ТЕХНОЛОГІЇ НАВЧАЛЬНОЇ ДІЯЛЬНСТІ ВИКЛАДАЧА ЗВО»
}

\section{Резван О. О.}

доктор педагогічних наук, професор, завідувач кафедри мовної підготовки, педагогіки та психології, Харківський національний університет імені О. М. Бекетова, м. Харків, Україна

У статті означено практичні підходи до вирімення проблеми підвищеення кваліфікації викладачів закладів вищої освіти; наголошено на ефективності набуття викладачами професійних компетенцій у процесі навчання на короткострокових тематичних курсах; представлено досвід організаиії підвищення кваліфікаиії викладачів у галузевому $3 В О$.

Ключові слова: підвищення кваліфікачії викладачів, короткострокові курси, форми підвищення кваліфікації, науково-практичний семінар, кваліфікаційний тренінг.

The article identifies practical approaches to solving the problem of professional development of teachers of higher education institutions; emphasis is placed on the effectiveness of teachers'acquisition of professional competencies in the process of teaching in short-term thematic courses; the experience of the organization of advanced training of teachers in branch institution of higher education is presented.

Key words: advanced training of teachers, short-term courses, forms of advanced training, scientific-practical seminar, qualification training.

Орієнтація української вищої освіти на загальноєвропейські освітні стандарти стала викликом щодо оновлення професійних компетенцій викладача (лектора і практика), які в цілому становлять його професійну компетентність. Особливо важливою в аспекті якісного перетворення особистості викладача визначаємо проблему набуття та розвитку методичної та педагогічної складових у процесі його фахової реалізації, що має бути організовано галузевими ЗВО. Варто зауважи- 
ти, що означене завдання стає саме проблемою для викладачів непедагогічних вишів, оскільки основна увага авторів освітніх програм, а відповідно - і навчальних планів - зорієнтована на відповідність викладачів профілю підготовки фахівців, а отже, їх педагогічні знання й методичні уміння набувають другорядного значення. Водночас у вимогах НАЗЯВО, що ставляться перед колективами проєктних груп ліцензованих спеціальностей актуалізуються питання педагогічної та методичної компетентності викладача.

Зауважуємо, що компетенція визначена індикатором якості освіти згідно із представленням структурної реформи вищої освіти у межах Болонського процесу. Це складне системне утворення, яке містить професійні знання, уміння, способи і техніки фахової діяльності, сукупність установок та орієнтацій, набутий досвід, що дає змогу викладачеві досягати високих освітніх результатів.

Кожна із професійних компетенцій (дисциплінарна, методична (дидактична), психолого-педагогічна, комунікативна, інформаційнотехнологічна, управлінсько-організаційна) має систематично оновлюватись і змістово та технологічно збагачуватись шляхом підвищення викладачем професійної кваліфікації. Зауважуючи на вимоги до підвищення кваліфікації науково-педагогічними працівниками, викладені у оновленому «Положенні про підвищення кваліфікації науковопедагогічних працівників» [1], звертаємо увагу на можливості регулярного професійного «тюнінгу» викладача, що набувається ним через особистісну рефлексію (усвідомлення змісту власної професійної недосконалості), вибір програми підвищення кваліфікації (тренінгу, семінару тощо) загальним обсягом 1 кредит (30 годин) на рік та набуття необхідної компетенції через навчання за обраною програмою.

Уважаємо, що саме такий шлях підвищення кваліфікації (а не один на 5 років - за розгорнутою програмою обсягом 180 годин, що представляє одну тему) буде найбільш ефективним для якісного оновлення викладачів вищої школи.

В аспекті зазначеного презентуємо апробований у ХНУМГ імені О.М. Бекетова шлях підвищення кваліфікації викладачів галузевих 3ВО, що реалізовується у програмах та формах постійно діючої науково-практичної школи-семінару та кваліфікаційного тренінгу «Сучасні технології викладання у вищій школі». Означений захід було створено 
Розділ І. Ціннісні орієнтири духовно-інтелектуального виховання, розвиток духовно-інтелектуальних якостей особистості в умовах співпраці й інклюзії

3 метою підвищення саме методичної та психолого-педагогічної компетенції викладачів, які не мають педагогічної освіти, але є фахівцями відповідної галузі й провадять педагогічну діяльність.

Кваліфікаційний тренінг «Сучасні технології викладання у вищій школі» реалізовувався упродовж 2019 - 2021 років у ХНУМГ імені О.М. Бекетова у різних, адаптованих щодо комфортності замовників, формах. У 2019 році було проведено широку презентацію авторських програм підвищення кваліфікації за партнерської участі фахівців із Південно-Моравського центру міжнародної мобільності (м. Брно, Чеська республіка), НТУ «ХПІ» (м. Харків), ХНПУ імені Г. С. Сковороди (м. Харків). Для вибору викладачів було запропоновано такі програми: «Ментальні карти як спосіб організації інформації» (доктор педагогічних наук, професор О .О. Резван, ХНУМГ імені О. М. Бекетова); «Дослідження ресурсів розвитку особистості на платформі графічного коучингу» (кандидат психологічних наук, доцент А. І. Книш, НТУ «ХПІ»); «Риторика. Особливості роботи з різними аудиторіями слухачів: як досягти успіху» (доктор педагогічних наук, професор Л. П. Ткаченко, ХНПУ імені Г. С. Сковороди); «Фасилітація як метод активного навчання. Підготовка воркшопу» (ст. викл. В. Ю. Бугаєва, ХНУМГ імені О. М. Бекетова); «Скрайбінг — новітня технологія візуалізації навчального матеріалу» (кандидат педагогічних наук, доцент А. М. Приходько, ХНУМГ імені О. М. Бекетова); «Вивчення чеської мови в аспекті професійної мобільності фахівця» (Мартін Хорн, викладач Південно-Моравського центру міжнародної мобільності (м. Брно, Чеська республіка); «Тимбілдинг як інструмент згуртування навчальної групи та педагога» (кандидат педагогічних наук, доцент В.В. Шаполова, НТУ «ХПІ»).

Організація роботи семінару-тренінгу відбувалась способом презентацій заявлених у програмі технологій із включенням до їх апробації учасників. Кожен із присутніх мав змогу обрати для участі 3 із заявлених у програмі семінару тренінги. Однак мала кількість часу, відведеного на роботу кожної програми (1 година), що була обумовлена обмеженою кількістю часу на проведення семінару в цілому, стала основним фактором зміни форми реалізації заходу.

У 2020 р. семінар-тренінг проходив у формі послідовних занять (2 години) упродовж 4 тижнів. Темами заходу стали: «Коучингові 
технології у навчанні», «Технологія скрайбінгу», «Організація публікації у журналах провідних науково-метричних баз: алгоритм дій та комунікація із редколегіями». Оскільки метою означеного заходу ставили не лише «тюнінгування» професійної компетентності педагогів, а й документальне підтвердження підвищення їх кваліфікації, важливим визначили питання відповідності обсягу навчання. Для того, щоб кожен із викладачів мав змогу за бажанням стати учасником усіх заявлених програм - створили зручний розклад занять, у якому жодна із програм не перетиналась із іншою, а отже - максимально можна було набути 30 годин підвищення кваліфікації (24 аудиторних і 6 самостійної роботи).

Слід визнати, що форма заходу, реалізована у 2020 році, проходила у режимі змішаної форми навчання і була найбільш оптимальною, оскільки за відгуками учасників, вони отримали реальну можливість опанувати нові технології у зручному режимі.

У зв'язку із карантинними вимогами, що ставились перед вишами у 2021 р., кількість викладачів-учасників у групі тренінгової програми при навчанні у класі не мала перевищувати 20 осіб. Вибір тематики тренінгових програм був зумовлений саме потребою викладачів посилити рівень компетентності організації навчальної діяльності в умовах змішаного навчання. Зважаючи на означене, було підготовлено та реалізовано тренінги за темами: «Культура створення навчальної презентації» (15 годин) та «Риторичні прийоми ефективної діяльності викладача 3ВО» (15 годин). Робота з викладачами відбувалась у режимі дистанційних та аудиторних занять - по 6 годин за кожною програмою та самостійної роботи - по 9 годин відповідно. Слід зауважити, що викладачі позитивно оцінили режим роботи тренінгів: по 4 години за кожною програмою одночасно, перерва на самостійну роботу - 1 тиждень і на закінчення - 2 години спілкування про результати виконаних завдань.

Єдність факторів: популярності представлених тренінгових програм, вимог до підвищення методико-педагогічної кваліфікації штатних викладачів та умови пандемії, - довели необхідність оперативного переходу системи підвищення кваліфікації викладачів закладів вищої освіти на дистанційну форму навчання, що спричинило створення додаткового курсу у програмі MOODLE, темами якого визначили: «Мен- 
тальні карти як спосіб організації інформації в навчальному процесі», «Коучингові технології у викладанні», «Візуальна комунікація в освіті». Слід зауважити, що означений курс було представлено в інтегрованому форматі, коли лекції за темою представлялись групі, створеній у програмі Teams, а завдання, виконувані слухачами, прикріплялись для перевірки у програмі MOODLE, що давало можливість досягти найбільшого ефекту сприйняття матеріалу та набуття компетенцій його практичного використання.

Ефективним способом підвищення педагогічної та методичної кваліфікації викладачів галузевих ЗВО видається організація кваліфікаційного тренінгу «Сучасні технології викладання у вищій школі», реалізація якого може диференціюватись: від формату реальної присутності слухачів в аудиторії до віддаленого навчання, здійснюваного у різних програмах дистанційного формату. Основною вимогою ефективності організації презентованого заходу визначаємо моніторинг та урахування запитів викладачів щодо тематичного вибору програм.

\section{Список використаних джерел:}

1. Деякі питання підвищення кваліфікації педагогічних та науково-педагогічних працівників. Постанова Кабміну України № 800 від 21.08.2019. URL https://zakon.rada.gov.ua/laws/show/800-2019-\%D0\%BF\#Text 